\title{
Um caso de medicina negativa
}

\author{
Communicação feita á Sociedade \\ Arnaldo Vieira de Carvalho, pelo \\ academico Eurico Branco Ribeiro.
}

\begin{abstract}
A MEDICINA não é sómente a positivação directa e indirecta de signaes anormaes na especie a que pertencemos. Se para o proprio diagnostico differencial procuramos alinhar ao lado dos symptomas e commemorativos presentes os symptomas e commemorativos ausentes, porque não ha-de a Medicina tambem possuir, encarada no geral, essa outra face que se caracteriza pela ausencia dos phenomenos pathologicos? Mas não se queira approximar a resposta á que apontaria o estado hygido, a condição ideal do organismo são, em que a inexistencia de signaes anormaes não admitte enquadrar-se o caso na moldura da Medicina.

Incoherencia?, paradoxo? - nada disso. Queremos nos referir aos falsos signaes pathologicos, a essa tela que se desenha á nossa visão mental e que a principio traz as cores de um caso clinico, para depois, examinados melhor os traços, se evidenciar na simulação, que ás vezes não percebemos.

E' o que chamariamos, se nos permittisseis a expressão, de "medicina negativa"

Da existencia dessa "medicina negativa" decorre o não estranhardes que vos relatemos, singelamente, um caso de falsos signaes pathologicos, occorrido em particularidades interessantes e corroborado concommitantemente por outro identico de que tivemos conhecimentö.

Casos taes, se não têm o merito de aguçar-nos a perspicacia diante de certas circumstancias que o consulente nos expõe, valem-nos pelo menos de recreação ao espirito concentrado pela aspereza das cogitações profissionaes.

Assim, haveis de permittir que vos desviemos a attenção do campo tanta vez intrincado e arduo da medicina pura para passeal-a alguns instantes pelo jardim florido da medicina negativa, onde, se encontramos motivos de distração, tambem podemos colher algum nectar venenoso para nós mesmos, senão para quem nos conduziu 'a elle, innocentemente.
\end{abstract}


Num dos primeiros dias de janeiro do corrente anno de 1927. Z. F., senhora de nossas relações, teve opportunidade de mostrar-nos um achado estranho que fizera nas proprias fezes, no dia seguinte a uma crise forte das colicas hepaticas de que vem soffrendo desde muitos, annos.

No recipiente que passou ás nossas mãos, viam-se dois grupos distinctos de substancias, que acreditava serem calculos expulsos durante a crise da vespera.

Um desses grupos era composto de oito ou dez corpusculos de contornos irregulares, cada qual ligeiramente maior do que um grão de milho e de cor verde garrafa.

O outro grupo constava de uma infinidade de corpusculos ainda muito menores - do tamanho da cabeça de um alfinete, se tanto cuja cor uniforme era de um tom escuro do amarello. Não havia completa igualdade de dimensões, mas o delineamento dos contornos mostrava-se o mesmo para todos: eram corpusculos periformes, de superficie lisa, um tanto ou quanto achatados.

A um relanço d'olhos, notamos que dois dos componentes do primeiro grupo eram facilmente diagnosticaveis: nada mais, nada menos do que vertebras de gallinha. Os demais deviam ser, sem duvida, da mesma origem: ossiculos ou pedaços de ossos mastigados e deglutidos com alimentos.

Diante dessa verificação, se já não bastasse a confissão da doente, que nos declarou que de facto costumava chupar e mesmo mastigar ossos de gallinha, principalmente do pescoço - a seç̧ão das peças nos mostraria, como depois nos mostrou, a nós e a varias outras pessoas, o aspecto nitido e indiscutivel das trabeculas de tecido osseo, dispensando-nos de uma comprovação microscopica.

Quanto ao segundo grupo, fizemos sentir que duvidavamos se se tratava ou não de calculos biliares. O laboratorio dar-nos-ia a ultima palavra. Nossa desconfiança, porém, era a de que estavamos em presença de alguma sementinha.

Mas a doente não accusava mudança de regime alimentar que justificasse a introducção no seu organismo de substancias capazes de reforçar as nossas suspeitas.

Aventámos, então, a hypothese medicamentosa. Ou com fins therapeuticos ou - por que não?, se estamos em puro dominio do monetarismo - ou para effeito commercial, visando-se para o remedio a fama de expulsor de calculos biliares, não teria o fabricante lançado mão de uma substancia vegetal activa, ou inocua, contendo semente semelhante, propositadamente ou não, á areia grossa que muita vez deflue das vias excretoras do figado?

Era certo que a doente acabava de tomar um vidro de "Cholelysina", mas comprimidos desse preparado foram por nós inteiramente dissolvidos em agua. 
Um medico a quem nesse dia mostrámos o achado, contando o caso, não titubeou em affirmar que o aspecto macroscopico era o de arreia biliar e que não podia haver duvidas sobre isso.

Não tão categoricos foram tres outros medicos, nossos illustres consocios, que, á vista do material que lhes apresentámos, permaneceram, pelo menos nos primeiros momentos, na mesma duvida que nos embaraçava. Alguns dias depois, mandava-nos dizer um delles, director de um dos mais conceituados laboratorios clinicos de São Paulo, que o diagnostico estava feito: tratava-se de sementes de figo.

De facto, já tinhamos observado que, á pressão com a unha sobre um plano resistente, os corpusculos se rompiam produzindo um ruido semelhante ao do rompimento de uma membrana forte que limita um espaço oco, e deixavam ver, entre os seus pedacicos esmagados, um blocozinho de cor differente, mais escuro, avermelhado.

Assim que nos chegou o recado do illustre analysta, tratámos de fazer a devida comprovação, para melhor illustrar esta communicação.

Com effeito, colhendo da calda um doce de figos as sementes que flutuavam, pudemos identifical-as com as que colhera das proprias fezes a doente atrás referida.

Convem frizar que o facto se passou logo após as festas de Natal e Anno Bom, época em que os figos passados são figura indispensavel nas reuniões familiares que os nossos costumes ordenam.

E' por isso que o caso por nós agora relatado não é, em São Paulo, nessa época, um caso unico. Não. Se as sementes de figo não são atacadas pelas diastases digestivas, claro é que ha-de encontral-as o doente que se preoccupa em catar nos proprios dejectos os residuos da litholyse que almeja.

E tanto assim é que, pelo mesmo tempo, um illustre cirurgião formado pela nossa escola registou na sua clinica particular um caso em tudo semelhante a esse que aqui narramos - certo doente do figado que lhe levou um punhado de sementes de figo, pensando se tratasse de areia hepatica, evidenciando-se a natureza do achado aos exames que se succederam á primeira impressão enganadora.

Por ahi se vê que a duvida pode estabelecer-se e que, consequentemente, a possibilidade de um engano é cabivel.

No caso de sementes de figo, talvez nenhuma consequencia desagradavel advenha, a não ser que se procure justificar pela expulsão de pseudos calculos uma therapeutica, pouco provavel mas possivel, que se torne prejudicial ao doente por uma insistencia intempestiva.

Outros falsos signaes haverá, entretanto, perante os quaes o medico, não se apercebendo de estar em face de um caso de medicina negativa, possa fazer prescripções damnosas ao cliente.

E' por isso que não será de todo desvalioso este trabalhinho que ousamos trazer á vossa consideração. 